\title{
Upregulation of CRISP-3 and kallikrein in stallion seminal plasma is associated with poor tolerance of cooled storage
}

\section{Kareskoski, Anna Maria}

2020-04

Kareskoski , A M , Palviainen, M , Johannisson, A \& Katila , T 2020 , ' Upregulation of CRISP-3 and kallikrein in stallion seminal plasma is associated with poor tolerance of cooled storage ' , Reproduction in Domestic Animals , vol. 55 , no. 4 , pp. 496-502 . https://doi.org/10.1111/rda.13643

http://hdl.handle.net/10138/324963

https://doi.org/10.1111/rda.13643

unspecified

acceptedVersion

Downloaded from Helda, University of Helsinki institutional repository.

This is an electronic reprint of the original article.

This reprint may differ from the original in pagination and typographic detail.

Please cite the original version. 
1 Upregulation of CRISP-3 and kallikrein in stallion seminal plasma is associated

6 Anna Maria Kareskoski $^{\mathrm{a}}$, Mari Palviainen ${ }^{\mathrm{b}}$, Anders Johannisson ${ }^{\mathrm{c}}$, Terttu Katila ${ }^{\mathrm{a}}$

\section{with poor tolerance of cooled storage}

\section{Short title: Stallion seminal plasma proteins}

${ }^{a}$ University of Helsinki, Faculty of Veterinary Medicine, Department of Production

Animal Medicine, Paroninkuja 20, 04920 Saarentaus, Finland

${ }^{b}$ University of Helsinki, Faculty of Veterinary Medicine, Department of Equine and Small Animal Medicine, Central Laboratory, P.O. Box 57, 00014 Helsinki

${ }^{\mathrm{c}}$ Swedish University of Agricultural Sciences, Faculty of Veterinary Medicine and Animal Science, Box 7054, 75007 Uppsala, Sweden

Corresponding author:

Maria Kareskoski; e-mail: maria.kareskoski@helsinki.fi, address: University of Helsinki, Faculty of Veterinary Medicine, Department of Production Animal Medicine, Paroninkuja 20, 04920 Saarentaus, Finland 


\section{Contents}

For unknown reasons, stallion fertility and sperm longevity during cooled storage of semen vary markedly between individuals. Spermatozoa from individual stallions react differently to the presence, or the removal, of seminal plasma (SP). The aim was to evaluate differences in protein content in stallion seminal plasma with either a positive or a negative effect on sperm chromatin integrity during storage. Stallion semen samples from different ejaculate fractions were stored at $5^{\circ} \mathrm{C}$ for $24 \mathrm{~h}$. Sperm survival was assessed after storage using a sperm chromatin structure assay. Protein expression in SP with either positive or negative effects on sperm survival during storage was studied using two-dimensional differential gel electrophoresis and liquid chromatography - mass spectrometry. Lower sperm chromatin integrity was associated with upregulation of the proteins kallikrein, CRISP-3, and HSP-1, while higher chromatin integrity was associated with upregulation of TIMP-2. In the spermrich fractions, kallikrein and CRISP-3 differed significantly between SP samples with differing effects on sperm chromatin integrity. In the sperm-poor fractions, TIMP-2 and HSP-1 differed significantly between the two SP groups. Differences in the seminal plasma proteome are associated with sperm longevity during cooled storage.

\section{Keywords:}

seminal plasma protein, spermatozoa, sperm chromatin integrity, sperm storage, stallion

\section{Introduction}

Stallion fertility and sperm longevity during cooled storage of semen vary markedly between individuals, but the reasons for this are largely unknown. The composition of 
stallion seminal plasma (SP) varies between stallions and different fractions of the ejaculate (Kareskoski et al. 2010a, Kareskoski et al. 2010b). The ejaculate fractions differ in sperm concentration and semen volume, with the first few jets, the spermrich fractions, containing the main portion of spermatozoa. The last sperm-poor fractions consist of secretions from the seminal vesicles with low sperm concentration (Tischner et al. 1974, Kosiniak 1975, Varner et al. 1987, Magistrini et al. 1995).

Reducing the proportion of SP to less than $10-20 \%$ for cooled storage of semen is beneficial for sperm survival during storage (Jasko et al. 1991, Pruitt et al. 1993, Braun et al. 1994, Todd et al. 2001, Alghamdi et al. 2002, Love et al. 2005), but the effects of SP on sperm survival can vary between the fractions of the ejaculate. Most studies have reported higher sperm motility and quality in sperm-rich fractions as compared to the sperm-poor fractions (Varner et al. 1987, Sieme et al. 2004, Kareskoski et al. 2011).

Variation between stallions in the effects of SP on spermatozoa is evident. It has been reported that spermatozoa from individual stallions react differently to the presence, or the removal, of SP (Padilla \& Foote 1991, Jasko et al. 1992, Akcay et al. 2006). Exchange studies, where spermatozoa from one stallion were stored in another stallion's SP, have also been carried out. Seminal plasma from some stallions seem to have a less negative, or even a beneficial, effect on sperm survival during storage (Aurich et al. 1996). It has been recommended that stallions producing semen with poor tolerance to cooling and storage should be evaluated for the effects of their SP on semen quality, and the semen processing technique modified accordingly (Brinsko et al. 2000, Love et al. 2005). 
71 Stallion SP contains several different types of proteins. The main SP proteins are proteins carrying fibronectin type II (Fn-2) modules, cysteine-rich secretory proteins (CRISPs), and spermadhesins. The suggested functions of SP proteins include involvement in several essential steps preceding fertilization, such as regulating capacitation, establishment of the oviductal sperm reservoir, modulation of the uterine immune response, sperm transport in the female genital tract, and gamete interaction and fusion (reviewed by Töpfer-Petersen et al. 2005).

The aim of this study was to evaluate protein expression in stallion SP with either positive or negative effects on sperm survival during storage. Two-dimensional differential gel electrophoresis and liquid chromatography - mass spectrometry was used for proteomic analysis and protein identification.

\section{Materials and methods}

\section{Animals}

Semen was collected during one breeding season from 43 stallions (ages 4 to 23 years) residing at nine stud farms in Finland. Twenty stallions were Standardbred trotters (ages 4 - 23 years), 17 Finnhorses (ages 8 - 23 years), four warmblood riding horses (ages 9 - 19 years) and two were ponies (ages 8 and 9 years). The breeding history and current use of the stallions was variable, with the stallions serving from 2 to 150 (median 14) mares during the study season. Most of the stallions (33 stallions) were used for collection of both fresh and transported semen, and four stallions were also used for natural breeding. The eight stallions that were selected for proteomic 
analyses were aged 10 to 23 years, and were used for commercial breeding regularly during the year of the study. Ethical approval was not required for this study according to the Finnish Act on the Protection of Animals Used for Scientific or Educational Purposes (497/2013).

\section{Semen collection}

The ejaculatory jets were collected as three to four fractions using one of the three types of artificial vaginas (AV): an open-ended artificial vagina equipped with a collection bag attached to a funnel (Krakow AV; Tischner et al. 1974) a Missouri AV with a collection bag (Kareskoski et al. 2011) or a computer-controlled fractioning phantom with an integrated AV (Equidame phantom, Haico Oy, Loimaa, Finland; Lindeberg et al. 1999), depending on stallion preference and stud farm. To provide comparable samples, fractions with the highest and lowest sperm concentrations within each ejaculate were included in the statistical analyses. The mean concentrations for the fractions were $300.0 \times 10^{6}$ and $54.0 \times 10^{6} \mathrm{sperm} / \mathrm{ml}$, respectively, with no significant differences in sperm concentration in fractions collected with the different methods. Of the stallions selected for proteomic analyses, all were collected using the open-ended AV, except for stallion E, which was collected with the modified closed AV.

\section{Semen processing and storage}

After semen collection, any gel was removed if present, and the volume of each fraction measured. The sperm concentration in each fraction was determined using a Bürker counting chamber. For the sperm chromatin structure assay (SCSA), a sample of $2-10 \times 10^{6}$ spermatozoa from each fraction of raw semen was pipetted into 
cryovials and TNE-buffer (9.48 g Tris-HCl, $52.6 \mathrm{NaCl}, 2.23 \mathrm{~g}$ disodium-EDTA, aqua ster. ad $600 \mathrm{~mL}, \mathrm{pH} 7.4$ ) was added (ad $1.5 \mathrm{~mL}$ in each vial). The SCSA samples were placed in liquid nitrogen vapor ( $3 \mathrm{~cm}$ above the liquid surface) for $10 \mathrm{~min}$, and then plunged into liquid nitrogen.

Each fraction was divided into two parts: one-half was centrifuged for the preparation of SP (SP samples), and the other half was processed for cooled storage (semen samples). A portion (10\%) of the volume of each fraction was combined to form a sample representing the whole ejaculate (WE). For cooled storage, semen samples were extended in a semen:extender ratio of 1:1 using skim milk extender (Kenney et al. 1975). Each fraction of the semen samples was divided into two centrifuge tubes and centrifuged at $500 \times \mathrm{g}(10 \mathrm{~min})$. After removal of the major part (about $5 \%$ was left) of the supernatant (i.e. extender and SP), the sperm pellet was extended in either: a) skim milk extender only (these samples stored without SP were named SP0 samples), or b) a combination of supernatant and skim milk extender (these samples stored with SP were named SP1). The final sperm concentration was $50 \times 10^{6}$ sperm $/ \mathrm{ml}$. The final SP to extender ratio in the SP1 samples was 1:2. The semen samples were stored in $1-\mathrm{mL}$ vials at $5^{\circ} \mathrm{C}$ for $24 \mathrm{~h}$. After the 24 -h cooled storage, $5 \mathrm{x}$ $10^{6}$ spermatozoa from each semen sample were pipetted into cryovials for SCSA, and TNE-buffer was added (ad $1.5 \mathrm{~mL}$ in each vial). The samples were placed in liquid nitrogen vapor ( $3 \mathrm{~cm}$ above the liquid surface) for 10min and plunged into liquid nitrogen.

The SP samples were centrifuged at $4000 \mathrm{xg}(15 \mathrm{~min})$, and the supernatant was filtered using 0.45- $\mu \mathrm{m}$ filters (Millex-HV, Millipore, Billerica, MA, USA). Protease 
inhibitor (Trasylol, 10000 Kallikrein Inactivator Units (KIU)/mL, Bayer Schering

Pharma, Berlin, Germany) was added to each sample (500 KIU/mL of SP) to decrease proteolytic activity on enzymes and other proteins. The SP samples were stored frozen in $1-\mathrm{mL}$ aliquots in $-75^{\circ} \mathrm{C}$ until analyzed.

\section{Sperm chromatin structure assay}

Sperm chromatin stability of sperm from both the raw and stored semen samples was measured as the susceptibility of sperm DNA to denaturation using the sperm chromatin structure assay (SCSA) as described by Evenson et al. (1999). Acridine orange was added to each thawed sample after exposure to an acid detergent solution that induces partial DNA denaturation in situ. Flow cytometry was then used to measure either red (abnormal sperm with denatured DNA) or green (normal sperm) fluorescence). Sperm DNA fragmentation index (DFI) was assessed by calculating the amount of red fluorescence divided by the total (red plus green) fluorescence, indicating the amount of denatured sperm DNA over the total DNA in each sperm cell.

\section{Selection of samples for proteomic analyses according to sperm survival during} cooled storage with or without seminal plasma

The samples of eight stallions were chosen for the proteomic analyses based on the effect of SP on sperm chromatin integrity during storage, represented here by the difference in DFI (diff-DFI) between semen samples stored with SP and the samples stored without SP $($ diff-DFI $=$ SP1 - SP0). The samples with the lowest and the highest diff-DFI ( -5.9 to $+0.8 \%$ and +10.6 to $+13.5 \%$, respectively) of all the stallions were selected, and the samples were grouped into two groups according to the diff- 
DFI. The effect of SP on sperm chromatin integrity was negative in the samples with high diff-DFI (group HIGH DIFF), and the effect of SP was positive or neutral in the samples with low diff-DFI (group LOW DIFF). The diff-DFI values varied significantly between the groups according to Student's t-test $(\mathrm{p}=0.008)$ (Table 1).

\section{Sample preparation for proteomic analysis and CyDye labelling}

Seminal plasma samples were prepared to proteomic analysis by precipitation with 2D Clean Up-kit and solubilized in $50 \mu \mathrm{l}$ of labeling buffer (7 M Urea, 2 M Thiourea, $4 \%$ CHAPS, $30 \mathrm{mM}$ Tris). The concentration of proteins in the samples was measured by using 2D Quant Kit according to manufacturer's instructions. The samples were then labeled with $\mathrm{Cy} 2, \mathrm{Cy} 3$ and Cy5 dyes (CyDye DIGE Fluor minimal dyes) according to Ettan two-dimensional difference gel electrophoresis (DIGE) protocol. Briefly, $50 \mu \mathrm{g}$ of protein from each sample were labeled with 400 pmol of the $\mathrm{Cy} 3$ and $\mathrm{Cy} 5$ dyes. Equal amount aliquots of each sample were combined to establish internal standard labeled with Cy2 dye. The labeling reaction was incubated 30 minutes on ice in the dark and halted by adding of $1 \mathrm{mM}$ lysine to the reaction following 10 minutes incubation as earlier. All materials and equipment by GE Healthcare, Piscataway, NJ, USA.

\section{Two-dimensional difference gel electrophoresis}

The labeled proteins were analyzed by two-dimensional difference gel electrophoresis (2D-DIGE) as described earlier (Ünlü et al. 1997). An immobilized pH gradient (IPG) strip (24 cm, pH 3-10, nonlinear, GE Healthcare, Piscataway, NJ, USA) was used for isoelectric focusing. IPG strips were loaded with $150 \mu \mathrm{g}$ of protein in total by using cup-loading method. Isoelectric focusing was performed using IPGPhor (GE 
Healthcare, Piscataway, NJ, USA) at $20^{\circ} \mathrm{C}$ as follows: $3 \mathrm{~h}$ at $150 \mathrm{~V}, 3 \mathrm{~h}$ at $300 \mathrm{~V}$, then linear ramping to $10000 \mathrm{~V}$ and $10000 \mathrm{~V}$ for $50000 \mathrm{Vh}$ with maximum current per strip being $75 \mu \mathrm{A}$. After focusing the isoelectric strips were prepared for the second dimension gels by incubation in I (50 mM Tris $\mathrm{pH} 8.8,6 \mathrm{M}$ urea, 30\% glycerol, 2\% sodium dodecyl sulphate (SDS), $0.2 \%$ bromophenol blue, with added $10 \mathrm{mg} / \mathrm{ml}$ dithiothreitol (DTT)) equilibrium buffer solution for 15 minutes. This was followed by equilibration in a II (50 mM Tris $\mathrm{pH} 8.8,6 \mathrm{M}$ urea, 30\% glycerol, $2 \%$ SDS, $0.2 \%$ bromophenol blue, supplemented with $25 \mathrm{mg} / \mathrm{ml}$ iodoacetamide) buffer solution for another 15 minutes. The prepared IPG strips were then placed on $12 \%$ sodium dodecyl sulphate polyacrylamide gels (SDS-PAGE) and sealed with overlay agarose (Bio-Rad, Hercules, CA, USA). Electrophoresis was initiated at $50 \mathrm{~V}$ for 30 minutes, which was followed by $400 \mathrm{~V}$ for 3 hours. The gels were scanned between lowfluorescence glass plates using an FLA-5100 laser scanner (Fujifilm, Tokyo, Japan) at wavelengths 473 (for Cy2), 532 (for Cy3) and $635 \mathrm{~nm}$ (Cy5) using voltages of 420, 410 and 400 V. After scanning the gels were stained by PlusOne silver staining kit (GE Healthcare, Piscataway, NJ, USA) without aldehyde.

\section{Image analysis and data processing}

The gel images were analyzed and statistically assessed using DeCyder 7.0 software (GE Healthcare, Piscataway, NJ, USA). First the gels were automatically analyzed using the batch processor function to normalize the $\mathrm{Cy} 2, \mathrm{Cy} 3$ and $\mathrm{Cy} 5$ images from each gel. Spot volumes were calculated and compared to Cy2 volumes (internal standard) to correct the inter-gel variations. In the biological variation module, the Cy2 images of all gels in groups were matched and the spot volumes compared. Approximately 1000 separate spots were detected on each gel. Protein spots 
demonstrating a minimum of 1.5 -fold difference in average spot volume ratios between groups using Student's $t$ test ( $p$-value less than 0.05 ) were chosen for identification.

\section{Protein identification}

Protein spots of interest were manually excised from the gel and digested in-gel using trypsin (Trypsin Gold, Promega, Madison, WI, USA) as described earlier (Shevchenko et al. 1996; Jensen et al. 1998). The peptides were extracted, vacuum dried (Vacufuge Plus vacuum concentrator, Eppendorf, Hamburg, Germany), centrifuged (Eppendorf microcentrifuge, Eppendorf, Hamburg, Germany) and redissolved in $20 \mu 15 \%$ formic acid. Digested peptides were de-salted using C18 ZipTips (Millipore, Burlington, MA, USA) according to the manufacturer's instructions. The resulting peptides were identified by fragment ion analysis with LC-MS/MS using Ultimate 3000 nano-LC system (Dionex, Sunnyvale, CA, USA) and QSTAR Elite hybrid quadruple TOF mass spectrometer (Applied Bioystems/MDS Sciex, Foster City, CA, USA) with nano-ESI ionization. The identification of proteins was performed using the local Mascot version 2.2 (Matrix Science, London, UK) against the in-house database with the following criteria: one missed cleavage allowed, carbamidomethyl modification of cysteine as a fixed modification, and oxidation of methionine as a variable modification.

\section{Results}

Approximately 1000 different proteins were expressed in the 2D-DIGE analysis. Only four proteins were significantly $(\mathrm{p}<0.05)$ differentially expressed in SP of the different storage groups (SP0 and SP1). The identified proteins were tissue inhibitor 
of metalloproteinase-2 (TIMP-2), horse seminal protein-1 (HSP-1), kallikrein, and cysteine-rich secretory protein-3 (CRISP-3).

In the sperm-rich fractions, kallikrein and CRISP-3 were upregulated in SP samples with high diff-DFI (i.e. a low rate of sperm survival during storage with SP). In the sperm-poor fractions, TIMP-2 was upregulated in SP samples with low diff-DFI (i.e. a high rate of sperm survival during storage), and HSP-1 was upregulated in samples with high diff-DFI (Table 2).

\section{Discussion}

Poor sperm survival during cooled storage in the presence of SP was associated with upregulation of the SP proteins kallikrein, CRISP-3, and HSP-1, while better sperm survival was associated with upregulation of TIMP-2. Sperm survival was evaluated using a chromatin structure assay, which has been shown to be correlated with sperm survival and fertility in stallions (Love et al. 2005, Johannisson et al.2018). The effects of SP on sperm motility can differ from those on sperm chromatin integrity, and SP can damage chromatin markedly while motility is maintained (Morrell et al. 2012). In this study, the stallions were categorized according to diff-DFI alone, because of the correlation between fertility and sperm chromatin integrity (Love 2005, Morrell et al. 2008).

Increased levels of CRISP-3 were associated with high diff-DFI, which reflects poor sperm survival during storage when SP is present. This is not necessarily directly linked to decreased fertility, which is a multifactorial trait. Most studies on CRISP-3 in stallion semen associate upregulation of the protein with increased fertility, 
whereas in our study upregulation was associated with decreased sperm survival during storage. Based on genomic studies, CRISP-3 is associated with stallion fertility and semen quality traits (Hamann et al. 2007, Novak et al. 2010, and Gottschalk et al. 2016). In raw semen, high levels of CRISP-3 in SP result in higher sperm motility and improved semen quality index (Restrepo et al. 2019), but in our study, higher levels of CRISP-3 decreased sperm longevity during storage.

Proteins that are correlated to fertility in raw or frozen semen may not be associated with sperm longevity during cooled storage. During storage, proteolytic changes in SP may alter the protein composition, as SP contains several different proteases and protease inhibitors (Laflamme \& Wolfner 2013). At present, the magnitude and significance of these proteolytic alterations are not known. The relationship between SP proteins and sperm survival during cooled storage has not previously been studied, except for our earlier study on SP proteins and cooled semen storage for $24 \mathrm{~h}$ where we found no significant correlation between the level of HSP-1 and sperm motility parameters (Kareskoski et al. 2011). The protein HSP-1 has been shown to protect other proteins against thermal and chemical stress conditions (Sankhala et al. 2012), and to prevent lipid peroxidation under oxidative stress (Kumar \& Swamy 2016). In our study, the levels of HSP-1 itself were higher in samples with poor sperm survival.

The mechanisms behind the association of these proteins with semen quality, freezability and fertility are largely unknown. The CRISP-3 protein is an androgenregulated protein expressed only in postpubertal horses (Fedorka et al. 2017). Associations between this protein and semen quality traits are not necessarily direct and causal, but rather indirect correlations of androgen-dependent traits. A possible 
role of CRISP-3 in the regulation of oxidative pathways in semen has been proposed (Restrepo et al. 2019), based on the high content of cysteine residues in CRISP-3 (Udby et al. 2005) and the contribution of these residues to oxidative reactions (Requejo et al. 2010). In human semen, seminal vesicular fluid makes SP a zincbinding medium after ejaculation. This can deplete spermatozoa of zinc and affect sperm chromatin decondensation (Björndahl \& Kvist 2010), and CRISP proteins could also enhance the appearance of DNA lesions in sperm (Rodrigues et al. 2016). This could explain the association between CRISP-3 and DNA injuries shown in our study.

Kallikrein was associated with high diff-DFI and DNA injuries during cooled storage. It is a protease similar to prostate-specific antigen (PSA) produced by the prostate gland in humans. Kallikrein and HSP-1 have earlier been shown to be negatively correlated to freezability (Jobim et al. 2011) and pregnancy rate, especially at low sperm concentrations and low dilution rates, when the amount of SP is high in relation to the number of spermatozoa. It was suggested that these proteins bind to spermatozoa and reduce their ability to fertilize the ovum (Novak et al. 2010). In our study, the negative effects of kallikrein on sperm chromatin integrity were found in the sperm-rich fraction of the ejaculate.

Both matrix metalloproteinases (MMPs) and their inhibitors (TIMPs) are found in SP (Baumgart et al. 2002). In our study, less sperm DNA damage during storage was associated with higher levels of TIMP-2. Similarly, high levels of TIMP-2 are associated with low levels of sperm DNA fragmentation in men (Belardin et al. 2019) and high fertility in bulls (McCauley et al. 2001, Viana et al. 2018). 
321 In the sperm-rich fractions, kallikrein and CRISP-3 differed significantly between HIGH DIFF and LOW DIFF stallions. In the sperm-poor fractions, TIMP-2 and HSP-

3231 differed significantly between these groups. The composition of these fractions

324 differs to some extent, but in our earlier study, there were no significant differences in 325 the amount of HSP-1 or CRISP-3 between fractions (Kareskoski et al. 2010b).

326 However, both sperm chromatin integrity (Björndahl \& Kvist 2010) and the function

327 of some SP proteins, such as kallikrein and CRISP-3 (Carvalho et al. 2002,

328 Schambony et al. 1998), are Zn-dependent, and hence the levels of $\mathrm{Zn}$ may affect the 329 observed fraction differences. The levels of $\mathrm{Zn}$ in stallion ejaculates are correlated to 330 sperm concentration (Pesch et al. 2006), which suggests that the seminal vesicles, 331 contributing mostly to the sperm-poor fractions of the ejaculate (Magistrini et al. 332 1995), are not the main source of $\mathrm{Zn}$ in stallion SP. In primates, $\mathrm{Zn}$ is mostly derived 333 from the prostate gland, and is therefore found in the sperm-rich fractions (Srivastava 334 et al. 1984). The Zn-regulated proteins kallikrein and CRISP-3 were significant for sperm chromatin integrity in only the sperm-rich fraction in our study.

\section{Conclusions} survival was associated with upregulation of TIMP-2.

Poor sperm survival during cooled storage when SP was present was associated with upregulation of the SP proteins kallikrein, CRISP-3, and HSP-1, while better sperm

343 None to declare. 
346 The data that support the findings of this study are available upon reasonable request

347 from the corresponding author. The data are not publicly available due to privacy

348 restrictions, e.g. their containing information that could compromise the privacy of

349 research participants.

350

$351 \quad$ References

352 Akcay, E., Reilas, T., Andersson, M., \& Katila, T. (2006). Effect of seminal plasma

353 fractions on sperm survival after cooled storage. Journal of Veterinary Medicine, 53, $354 \quad$ 481-485. doi: $10.1111 / \mathrm{j} .1439-0442.2006 .00882 . \mathrm{x}$

355

Alghamdi, A. S., Troedsson, M. H., Xue, J. L., \& Crabo, B. G. (2002). Effect of seminal plasma concentration and various extenders on postthaw motility and glass wool-Sephadex filtration of cryopreserved stallion semen. American Journal of

Veterinary Research, 63, 880-885. doi: 10.2460/ajvr.2002.63.880

Aurich, J.E., Kühne, A., Hoppe, H., \& Aurich, C. (1996). Seminal plasma affects membrane integrity and motility of equine spermatozoa after cryopreservation. Theriogenology, 46, 791-797. doi: 10.1016/s0093-691x(96)00237-3 differences in matrix metalloproteinase (MMP)-2, but not in MMP-9, tissue inhibitor of metalloproteinase (TIMP)-1 or TIMP-2, in seminal plasma of normozoospermic and azoospermic patients. Human Reproduction, 17, 2919-2923. 
371 Belardin, L. B., Antoniassi, M. P., Camargo, M., Intasqui, P., Fraietta, R., \& Bertolla,

372 R. P. (2019). Semen levels of matrix metalloproteinase (MMP) and tissue inhibitor of 373 metalloproteinases (TIMP) protein families members in men with high and low sperm 374 DNA fragmentation. Scientific Reports, 29, 903. doi: 10.1038/s41598-018-37122-4 375 model including zinc bridges. Molecular Human Reproduction, 16, 23-29. doi: 10.1093/molehr/gap099

Braun, J., Sakai, M., Hochi, S., \& Oguri, N. (1994). Preservation of ejaculated and epididymal stallion spermatozoa by cooling and freezing. Theriogenology, 41, 809818. doi: $10.1016 / 0093-691 \times(94) 90497-7$ storage. Theriogenology, 54, 129-136. doi: 10.1016/S0093-691X(00)00331-9 spermatozoa and polymorphonuclear neutrophils. Biology of Reproduction, 85, 157164. doi: 10.1095/biolreprod.110.084491

392

393 Evenson, D. P., Jost, L. K., Marshall, D., Zinaman, M. J., Clegg, E., Purvis, K., de 394 Angelis, P., \& Claussen, O. P. (1999). Utility of the sperm chromatin structure assay 
397

401

402

403

404

405

406

407

408

409

410

411

412

413

as a diagnostic and prognostic tool in the human fertility clinic. Human Reproduction, 14, 1039-49. doi: 10.1093/humrep/14.4.1039

Fedorka, C. E., Scoggin, K. E., Squires, E. L., Ball, B. A., \& Troedsson, M. H. T. (2017). Expression and localization of cysteine-rich secretory protein-3 (CRISP-3) in the prepubertal and postpubertal male horse. Theriogenology, 87, 187-192. doi: 10.1016/j.theriogenology.2016.08.027

Gottschalk, M., Metzger, J., Martinsson, G., Sieme, H., \& Distl, O. (2016). Genomewide association study for semen quality traits in German Warmblood stallions. Animal Reproduction Science, 171, 81-86. doi: 10.1016/j.anireprosci.2016.06.002

Hamann, H., Jude, R., Sieme, H., Mertens, U., Töpfer-Petersen, E., Distl, O., \& Leeb, T. (2007). A polymorphism within the equine CRISP3 gene is associated with stallion fertility in Hanoverian warmblood horses. Animal Genetics, 38, 259-264. doi: 10.1111/j.1365-2052.2007.01594.x

Jasko, D. J., Moran, D. M., Farlin, M. E., \& Squires, E. L. (1991). Effect of seminal plasma dilution or removal on spermatozoa motion characteristics of cooled semen. Theriogenology, 35, 1059-1067.

Jasko, D. J., Hathaway, V. L., Schaltenbrand, V. L., Simper, W. D., \& Squires, E. L. (1992). Effect of seminal plasma and egg yolk on motion characteristics of cooled stallion spermatozoa. Theriogenology, 37, 1241-1252. 
Jensen, O. N., Larsen, M. R., \& Roepstorff, P. (1998). Mass spectrometric identification and micro characterization of proteins from electrophoretic gels: strategies and applications. Proteins: Structure, Function, and Bioinformatics, 33, 74 89.

Jobim, M. I., Trein, C., Zirkler, H., Gregory, R. M., Sieme, H., \& Mattos, R. C. (2011). Two-dimensional polyacrylamide gel electrophoresis of equine seminal plasma proteins and their relation with semen freezability. Theriogenology, 76, 76571. doi: 10.1016/j.theriogenology.2011.04.010

Johannisson, A., Figueiredo, M. I., Al-Kass, Z., \& Morrell, J. M. (2018).

Simultaneous evaluation of superoxide content and mitochondrial membrane potential in stallion semen samples provides additional information about sperm quality. Animal Reproduction Science, 192, 290-297. doi: 10.1016/j.anireprosci.2018.03.030

Kareskoski, A. M., Reilas, T., Sankari, S., Andersson, M., Güvenc, K., \& Katila, T. (2010a). Alkaline and acid phosphatase, $\beta$-glucuronidase, and electrolyte levels in fractionated stallion ejaculates. Reproduction in Domestic Animals, 45, e369-e374. doi: $10.1111 / \mathrm{j} .1439-0531.2009 .01579 . \mathrm{x}$

Kareskoski, A. M., Rivera del Alamo, M. M., Güvenc, K., Reilas, T., Calvete, J. J., Rodriguez-Martinez, H., Andersson, M., \& Katila, T. (2010b). Protein composition of seminal plasma in fractionated stallion ejaculates. Reproduction in Domestic Animals, 46, e79-e84. doi: 10.1111/j.1439-0531.2011.01789.x 
Kareskoski, A. M., Sankari, S., Johannisson, A., Kindahl, H., Andersson, M., \& Katila, T. (2011). The association of the presence of seminal plasma and its components with stallion fertility and sperm longevity in fractionated ejaculates. Reproduction in Domestic Animals, 46, 1073-1081. doi: 10.1111/j.14390531.2011.01789.x

Kenney, R. M., Bergman R. V., Cooper, W. L., \& Morse, G. W. (1975). Minimal contamination techniques for breeding mares: techniques and preliminary findings. Proceedings of the 21st Annual Convention of the American Association of Equine Practitioners, 327-336.

Kosiniak, K. (1975). Characteristics of the successive jets of ejaculated semen of stallions. Journal of Reproduction and Fertility Supplement, 23, 59-61.

Kumar, C. S., \& Swamy, M. J. (2016). HSP-1/2, a major horse seminal plasma protein, acts as a chaperone against oxidative stress. Biochemical and Biophysical Research Communications, 473, 1058-1063. doi: 10.1016/j.bbrc.2016.04.015

Laflamme, B. A., \& Wolfner, M. F. (2013). Identification and function of proteolysis regulators in seminal fluid. Molecular Reproduction and Development, 80, 80-101. doi: $10.1002 / \mathrm{mrd} .22130$

Lindeberg, H., Karjalainen, H., Koskinen, E., Katila, T. (1999). Quality of stallion semen obtained by a new semen collection phantom (Equidame) versus a Missouri 
471

47

473

474

475

476

477

478

479

480

481

482

483

484

485

486

487

488

489

490

491

492

493

artificial vagina. Theriogenology, 51, 1157-1173. doi: 10.1016/S0093-

691X(99)80019-3

Love, C. C., Brinsko, S. P., Rigby, S. L., Thompson, J. A., Blanchard, T. L., \& Varner, D. D. (2005). Relationship of seminal plasma level and extender type to sperm motility and DNA integrity. Theriogenology, 63, 1584-1591.

doi: 10.1016/j.theriogenology.2004.05.030

Love, C. C. (2005). The sperm chromatin structure assay: a review of clinical applications. Animal Reproduction Science, 89, 39-45.

doi:10.1016/j.anireprosci.2005.06.019

Magistrini, M., Lindeberg, H., Koskinen, E., Beau, P., \& Seguin, F. (2000).

Biophysical and ${ }^{1} \mathrm{H}$ magnetic resonance spectroscopy characteristics of fractionated stallion ejaculates. Journal of Reproduction and Fertility Supplement, 56, 101-110.

McCauley, T. C., Zhang, H. M., Bellin, M. E., \& Ax, R. L. (2001). Identification of a heparin-binding protein in bovine seminal fluid as tissue inhibitor of metalloproteinases-2. Molecular Reproduction and Development, 58, 336-341. doi: 10.1002/1098-2795(200103)58:3<336::AID-MRD12>3.0.CO;2-Z

Morrell, J. M., Johannisson, A., Dalin, A. M., Hammar, L., Sandebert, T., RodriguezMartinez, H. (2008). Sperm morphology and chromatin integrity in Swedish warmblood stallions and their relationship to pregnancy rates. Acta Veterinaria Scandinavica, 50, 2-8. doi: 10.1186/1751-0147-50-2. 
Morrell, J. M., Pihl, J., Dalin, A. M., Johannisson, A. (2012). Restoration of seminal plasma to stallion spermatozoa selected by colloid centrifugation increases sperm progressive motility but is detrimental to chromatin integrity. Theriogenology, 78, 345-52. doi: 10.1016/j.theriogenology.2012.02.009.

Novak, S., Smith, T. A., Paradis, F., Burwash, L., Dyck, M. K., Foxcroft, G. R., \& Dixon, W. T. (2010). Biomarkers of in vivo fertility in sperm and seminal plasma of fertile stallions. Theriogenology, 74, 956-67.

doi:10.1016/j.theriogenology.2010.04.025

Padilla, A. W., \& Foote, R. H. (1991). Extender and centrifugation effects on the motility patterns of slow-cooled stallion spermatozoa. Journal of Animal Science, 69, 3308-3313. doi: $10.2527 / 1991.6983308 x$

Pesch, S., Bergmann, M., \& Bostedt, H. (2006). Determination of some enzymes and macro- and microelements in stallion seminal plasma and their correlations to semen quality. Theriogenology, 66, 307-313. doi: 10.1016/j.theriogenology.2005.11.015

Pruitt, J. A., Arns, M. J., \& Pool, K. C. (1993). Seminal plasma influences recovery of equine spermatozoa following in vitro culture $\left(37^{\circ} \mathrm{C}\right)$ and cold-storage $\left(5^{\circ} \mathrm{C}\right)$. Theriogenology, 39, 291.

Requejo, R., Hurd, T. R., Costa, N. J., \& Murphy, M. P. (2010). Cysteine residues exposed on protein surfaces are the dominant intramitochondrial thiol and may protect 
524

525

against oxidative damage. FEBS Journal, 277, 1465-1480. doi: 10.1111/j.17424658.2010.07576.x

Restrepo, G., Rojano, B., \& Usuga, A. (2019). Relationship of cysteine-rich secretory protein-3 gene and protein with semen quality in stallions. Reproduction in Domestic Animals, 54, 39-45. doi: 10.1111/rda.13309

Rodrigues, M. F., Trentin, J. M., Boligon de Araujo, Centeno, L. A. M., Schenatto, R. O., Pessoa, G. A., Neves, A. P., \& Rubin, M. I. B. (2016). Seminal plasma: Effect on motility, membrane functionality, and spermatic chromatin dispersion of equine sperm treated with N-acetyl-L-cysteine at $5^{\circ} \mathrm{C}$. Acta Scientiae Veterinariae, 44, 1371.

Sankhala, R. S., Kumar, C. S., Singh, B. P., Arangasamy, M. J., \& Swamy, M. J. (2012). HSP-1/2, a major protein of equine seminal plasma, exhibits chaperone-like activity. Biochemical and Biophysical Research Communications, 427, 18-23. doi: 10.1016/j.bbrc.2012.08.120

Shimokawa, K., Katayama, M., Matsuda, Y., Takahashi, H., Hara, I., Sato, H., \& Kaneko, S. (2002). Matrix metalloproteinase (MMP)-2 and MMP-9 activities in human seminal plasma. Molecular Human Reproduction, 8, 32-36. doi: $10.1093 / \mathrm{molehr} / 8.1 .32$

Shevchenko, A., Wilm, M., Vorm, O., \& Mann, M. (1996). Mass spectrometric sequencing of proteins from silver-stained polyacrylamide gels. Analytical Chemistry 68, 850-858. doi: 10.1021/ac950914h 
544 Sieme, H., Katila, T., \& Klug, E. (2004). Effect of semen collection practices on

545 sperm characteristics before and after storage and on fertility of stallions.

546 Theriogenology, 61, 769-784. doi: 10.1016/s0093-691x(03)00251-6

547

548 Srivastava, A., Chowdhury, A. R., \& Setty, B. S. (1984). Zinc content in the

549 epididymis, vas deferens, prostate, and seminal vesicles of juvenile rhesus monkey

550 (Macaca mulatta): effect of androgen and estrogen. Prostate, 5, 153-8.

551 doi: 10.1002/pros.2990050205

552

553 Tischner, M., Kosiniak, K., \& Bielanski, W. (1974). Analysis of pattern of ejaculation

554 in stallions. Journal of Reproduction and Fertility, 41, 329-335.

555 doi: 10.1530/jrf.0.0410329

556

557 Todd, P., Arns M. J., Chenoweth, P., \& Schultz, B. (2001). Influence of seminal

558 plasma and processing on cold-stored stallion spermatozoa. Animal Reproduction

559 Science, 68, 335-336.

560

561 Troedsson, M. H. T., Doty, A., Macpherson, M. L., Connor, M. C., Verstegen, J. P.,

562 Pozor, M. A., Buhi, W. C. (2010). CRISP-3 in equine seminal plasma is involved in

563 selective uterine sperm transport. Animal Reproduction Science, 121, 192-193.

564

565 Töpfer-Petersen, E., Ekhlasi-Hundrieser, M., Kirchhoff, C., Leeb, T., \& Sieme, H.

566 (2005). The role of stallion seminal plasma proteins in fertilisation. Animal

567 Reproduction Science, 89, 159-170. doi: 10.1016/j.anireprosci.2005.06.018 
569 Udby, L., Calafat, J., Sørensen, O.E., Borregaard, N., \& Kjeldsen, L. (2002).

570 Identification of human cysteine-rich secretory protein 3 (CRISP-3) as a matrix

571 protein in a subset of peroxidase-negative granules of neutrophils and in the granules

572 of eosinophils. Journal of Leukocyte Biology, 72, 462-9. doi:10.1189/jlb.72.3.462

573

574 Udby, L., Bjartell, A., Malm, J., Egesten, A., Lundwall, K., Cowland, J., \& Kjeldsen,

575 I. (2005). Characterization and localization of cysteine-rich secretory protein 3

576 (CRISP-3) in the human male reproductive tract. Journal of Andrology, 26, 333-342.

577 doi: 10.2164/jandrol.04132

578

579 Ünlü, M., Morgan, M. E., \& Minden, J. S. (1997). Difference gel electrophoresis: a

580 single gel method for detecting changes in protein extracts. Electrophoresis, 18, 2071-

582

583 Usuga, A., Rojano, B., \& Restrepo, G. (2018). Association of the cysteine-rich 584 secretory protein-3 (CRISP-3) and some of its polymorphisms with the quality of 585 cryopreserved stallion semen. Reproduction, Fertility and Development, 30, 563586 569. doi: 10.1071/RD17044

587

588 Varner, D. D., Blanchard, T. L., Love, C. C., Garcia, M. C., \& Kenney, R. M. (1987).

589 Effects of semen fractionation and dilution ratio on equine spermatozoa motility

590 parameters. Theriogenology, 28, 709-723. doi: 10.1016/0093-691x(87)90288-3

591 
593 Viana, A. G. A., Martins, A. M. A., Pontes, A. H., Fontes, W., Castro, M. S., Ricart,

594 C. A. O., Sousa, M. V., Kaya, A., Topper, E., Memili, E., \& Moura, A. A. (2018).

595 Proteomic landscape of seminal plasma associated with dairy bull fertility. Scientific

596 Reports, 8, 16323. doi: 10.1038/s41598-018-34152-w

597

598

599

600 
601 Table 1. DNA fragmentation index (DFI) in semen samples stored at $5^{\circ} \mathrm{C}$ for $24 \mathrm{~h}$ with 602 or without seminal plasma (SP). Difference in DFI $=($ DFI when stored with SP) -

603 (DFI when stored without SP).

\begin{tabular}{c|c|ccc}
\hline & & \multicolumn{3}{|c}{ DFI (\%) after storage } \\
Stallion & DFI (\%) before storage & & & Difference in \\
& & Stored without SP & Stored with SP & \begin{tabular}{c} 
DFI \\
\hline A
\end{tabular} \\
B & 10.3 & 11.8 & 5.8 & -5.9 \\
C & 22.7 & 29.7 & 28.5 & -1.2 \\
D & 11.1 & 13.5 & 13.5 & -0.01 \\
E & 17.6 & 25.0 & 25.8 & 0,8 \\
F & 17.3 & 21.6 & 32.2 & 10.6 \\
G & 22.4 & 30.6 & 41.6 & 11.0 \\
H & 11.1 & 7.6 & 19.5 & 11.9 \\
\hline
\end{tabular}

604

605 


\begin{tabular}{|c|c|c|c|c|c|c|c|}
\hline Gel ID & $\begin{array}{c}\text { Identified } \\
\text { protein }\end{array}$ & $\begin{array}{c}\text { Accession } \\
\text { number }\end{array}$ & pI & $\begin{array}{c}\text { Molecular } \\
\text { weight (kDa) }\end{array}$ & $\begin{array}{c}\text { Sequence coverage } \\
(\%)\end{array}$ & MASCOT score & Upregulation in \\
\hline \multicolumn{8}{|c|}{ Seminal plasma in sperm-rich fractions } \\
\hline 6 & Kallikrein & 18250639 & 5.4 & 21.4 & 13.1 & 71 & Low sperm survival \\
\hline 5 & CRISP-3 & 3023562 & 7.4 & 27.0 & 21.2 & 111 & Low sperm survival \\
\hline \multicolumn{8}{|c|}{ Seminal plasma in sperm-poor fractions } \\
\hline 2 & TIMP-2 & 135853 & 7.4 & 24.0 & 7.3 & 60 & High sperm survival \\
\hline 5 & HSP-1 & 1168021 & 8.2 & 14.0 & 42.9 & 112 & Low sperm survival \\
\hline
\end{tabular}

Table 2. Seminal plasma proteins with significant $(\mathrm{p}=0.05)$ upregulation in samples with a low rate of sperm survival during cooled storage with seminal plasma (evaluated as changes in sperm chromatin integrity), compared with samples with a high rate of sperm survival during cooled storage. (CRISP-3 = cysteine-rich secretory protein-3; TIMP-2 = tissue inhibitor of metalloproteinase-2; HSP-1 = horse seminal protein-1; pI = isoelectric point). 